\title{
Prediksi Penambahan Kasus Covid-19 di Indonesia Melalui Pendekatan Time Series Menggunakan Metode Exponential Smoothing
}

\author{
Calvin Mikhailouzna Gibran ${ }^{1}$, Sulis Setiyawati ${ }^{2}$, Febri Liantoni ${ }^{3}$ \\ ${ }^{1,2,3}$ Pendidikan Teknik Informatika dan Komputer, Fakultas Keguruan dan Ilmu Pendidikan, \\ Universitas Sebelas Maret \\ 19alvinmikhailouzna@gmail.com, ${ }^{2}$ sulissetiyawati57@gmail.com, ${ }^{3}$ febri.liantoni@gmail.com
}

Submitted Date: February $06^{\text {th }}, 2021$

Revised Date: June 04 ${ }^{\text {th }}, 2021$
Reviewed Date: June 02 ${ }^{\text {nd }}, 2021$

Accepted Date: June $15^{\text {th }}, 2021$

\begin{abstract}
The Covid-19 pandemic in Indonesia has emerged starting in 2020. To know the development of cases, a good calculation is needed. A prediction system can help in analyzing accurate data on positive causes, cures, and deaths. The right prediction or forecast can be the answer to the question of the impact that will occur, forecasting will provide an overview to the government and the community so that it is hoped that related parties can prepare for future impacts or even reduce the number of cases growth. In this study, the Exponential Smoothing method was used as a prediction calculation. This method is simple but effective in producing accurate predictions. Forecasting data used comes from the Indonesian government with the assumption that the data is valid and reliable. Based on research that has been carried out to predict the increase in new cases of the Indonesian National Covid-19, the best alpha $(\alpha)$ value is 0.33 with an SSE of 1048027,939 . This shows that the number of cases is increasing. The results of forecasting in this study using the time series approach and the SES method are more suitable for predicting the percentage increase in cases than knowing the exact number.
\end{abstract}

Keywords: Covid-19; prediction; time series forecasting; exponential smoothing

\begin{abstract}
Abstrak
Pandemi Covid-19 di Indonesia telah muncul mulai tahun 2020. Untuk mengetahui perkembangan kasus diperlukan perhitungan yang baik. Suatu sistem prediksi dapat membantu dalam menganalisis data kasus positif, kesembuhan, dan kematian yang akurat. Prediksi atau peralaman yang tepat dapat menjadi jawaban atas pertanyaan dampak yang akan terjadi, peramalan akan memberikan gambaran kepada pemerintah dan masyarakat sehingga diharapkan pihak terkait dapat mempersiapkan dampak yang akan datang atau bahkan mengurangi angka pertumbuhan kasus. Pada penelitian ini, metode Exponential Smoothing digunakan sebagai perhitungan prediksi. Metode ini sederhana namun efektif dalam menghasilkan prediksi yang akurat. Data peramalan yang digunakan berasal dari pemerintah Indonesia dengan asumsi bahwa data tersebut valid dan dapat diandalkan. Berdasarkan penelitian yang sudah dilakukan untuk meramalkan pertambahan kasus baru Covid-19 Nasional Indonesia diperoleh nilai alpha $(\alpha)$ terbaik sebedar 0.33 dengan SSE bernilai 1048027.939. Hal ini menunjukkan jumlah kasus yang semakin bertambah. Sehingga hasil dari peramalan pada penelitian ini dengan menggunakan pendekatan time series dan metode SES lebih cocok untuk mengetahui prediksi presentase kenaikan kasusnya saja dibandingkan mengetahui angka pastinya.
\end{abstract}

Kata Kunci: Covid-19; prediksi; peramalan time series; exponential smoothing.

\section{Pendahuluan}

Adanya wabah Covid-19 yang telah muncul didunia menjadi perhatian semua pihak disebabkan tingkat penyebaran wabah yang cepat dan banyaknya kasus kematian yang terjadi
(Parhusip, 2020; Zhang et al., 2020). Pada tanggal 11 Maret 2020, Covid-19 ditetapkan sebagai pandemi oleh World Health Organization (WHO). Pandemi Covid-19 ini menyebar dengan sangat cepat ke berbagai negara di seluruh dunia. Covid- 
19 merupakan penyakit menular yang disebabkan oleh Virus SARS-COV-2 atau Virus Corona yang dapat menginfeksi hewan (seperti kucing dan anjing) dan juga dapat menular dari manusia ke manusia. Covid-19 merupakan jenis penyakit baru, sehingga manusia belum mempunyai kekebalan tubuh yang cukup untuk menangkal virus SARSCOV-2. Sampai saat ini vaksin dan obat dari virus ini belum juga ditemukan, sehingga banyak peneliti di penjuru dunia yang berlomba-lomba mencari vaksin dan obat virus ini.

Virus SARSCov-2 atau Virus Corona merupakan penyebab dari munculnya penyakit Covid-19 (Corona Virus Disease 2019). Pada desember 2019, kasus pertama munculnya virus ini terjadi di provinsi Wuhan, China. Virus ini menyerang sistem pernapasan manusia dengan gejala serupa sakit flu pada umumnya, diantaranya batuk, demam, letih, dan sesak napas (Rusyida \& Pratama, 2020). Manusia akan merasakan batuk dan demam ketika terinfeksi (Liu et al., 2020). Namun berbeda dengan flu pada umumnya, virus ini berkembang dengan cepat serta dapat menular dari manusia ke manusia, sehingga bisa mengakibatkan infeksi paru-paru yang lebih parah (Yuliana, 2020). Pada manusia terjadinya gagal organ yang bisa menyebabkan kematian, terutama pada pasien terjangkit yang sebelumnya memiliki masalah kesehatan dan umur lansia (Mona, 2020).

Sejak masuknya Covid-19 di Indonesia, pemerintah Indonesia menyatakan darurat bencana pada tanggal 29 Februari 2020 hingga 29 Mei 2020 sebagai upaya untuk menghadapi pandemi corona. Hal ini dilakukan oleh pemerintah agar dapat menyelesaikan pandemi ini dengan mensosialisasikan gerakan social distancing atau physical distancing yang merupakan pembatasan interaksi sosial antar manusia maupun kegiatan yang melibatkan banyak orang atau kelompok kepada masyarakat Indonesia (Parhusip, 2020).

Oleh karena itu diperlukan adanya penelitian untuk memberikan prediksi pada banyaknya kasus terjangkit Covid-19 pada waktu selanjutnya berdasarkan data yang sudah ada sebelumnya atau time series. Mengingat negara Indonesia memiliki jumlah penduduk yang banyak sehingga pendataan masyarakat yang terjangkit Covid-19 harus selalu dilakukan secara cepat agar dapat memberikan penjelasan kepada semua pihak untuk melakukan tindakan pencegahan dan juga isolasi mandiri agar mata rantai penyebaran Covid-19 dapat dihentikan.

Pada penelitian sebelumnya, penulis menggunakan metode Double Exponential
Smoothing untuk memprediksi nilai bitcoin dalam pengambilan keputusan dalam perdagangan. Pada penelitian ini diperoleh nilai alpha 0.9 sebagai nilai terbaik (Liantoni \& Agusti, 2020). Berdasarkan latar belakang tersebut maka penelitian ini bertujuan untuk memprediksi penambahan kasus Covid-19 di Indonesia menggunakan pendekatan time series dengan metode Exponential Smoothing.

\section{Metodologi}

Peramalan (forecasting) merupakan jenis ilmu yang digunakan untuk meramalkan kejadian dimasa depan dengan menggunakan data historis dan memproyeksikan data tersebut ke masa yag akan datang dengan model pendekatan sistematis (Heizer \& Render, 2011). Proses mengumpulkan data yang relevan serta pemilihan metode predeksi yang sesuai merupakan dua hal utama dalam proses peramalan yang akurat. Adapun kegunaan peramalan antara lain sebagai berikut: 1) Media yang efektif dan efisien dalam proses perencanaan; 2) Untuk penentuan kebutuhan sumber daya dimasa yang akan datang; dan 3) Pembuatan keputusan yang tepat.

Data yang digunakan dalam prediksi berupa data time series. Time series merupakan sekumpulan observasi data yang terurut dalam suatu waktu. Frekuensi waktu dapat berupa detik, menit, jam, hari, minggu, bulan dan tahun. Pada peramalan data time series perlu memperhatikan komponen atau pola data (Montgomery, n.d.).

Exponential Smoothing merupakan algoritma perkembangan dari moving average, yang umunya dipakai dalam menyelesaikan permasalahan data time series (Baharaeen \& Masud, 1986; Rosas \& Guerrero, 1994). Exponential smoothing atau penghalusan eksponensial merupakan pengembangan metode prediksi rata-rata bergerak dengan menambahkan bobot secara eksponensial atau bertingkat untuk data terbaru sehingga semakin terbaru datanya, semakin besar pula bobotnya.

Karena data terbaru dianggap lebih relevan sehingga diberikan bobot yang lebih besar. Parameter penghalusan ditunjukkan dengan simbol a (alpha). Rumus untuk menghitung exponential smoothing:

$\mathrm{Ft}=\mathrm{Ft}-1+\alpha(\mathrm{Dt}-1+\mathrm{Ft}-1)$

Di mana $\mathrm{Ft}$ merupakan nilai prakiraan permintaan sekarang, Ft-1 merupakan nilai prakiraan permintaan yang lalu, $\alpha$ merupakan 
konstanta eksponensial, Dt-1 merupakan permintaan nyata. Dengan penentuan nilai konstanta pada metode peramalan exponential smoothing.

$$
\alpha=2 /(n+1)
$$

Di mana $\alpha$ merupakan nilai konstanta dan $n$ merupakan jumlah periode waktu

\section{Hasil Dan Pembahasan}

Pada penelitian ini, kami menggunakan dataset pertambahan per hari angka positif Covid-19 Indonesia secara Nasional. Dataset dimulai dari tanggal $28 \mathrm{Mei}$ 2020 - 6 Juni 2020, dengan feature "Pertambahan". Contoh kasus pertambahan positif Covid-19 untuk 10 hari ditunjukkan pad Tabel 1.

Tabel 1. Dataset Pertambahan Positif Covid-19 bulan mei dan juni

\begin{tabular}{|c|c|}
\hline Tanggal & Kasus Baru \\
\hline 28 May & 687 \\
\hline
\end{tabular}

\begin{tabular}{|c|c|}
\hline 29 May & 678 \\
\hline 30 May & 557 \\
\hline 31 May & 700 \\
\hline 1 Jun & 467 \\
\hline 2 Jun & 609 \\
\hline 3 Jun & 684 \\
\hline 4 Jun & 585 \\
\hline 5 Jun & 703 \\
\hline 6 Jun & 993 \\
\hline
\end{tabular}

Dataset tersebut dapat dimanfaatkan untuk meramalkan angka pertambahan Covid-19 satu hari kedepan, pendekatan time series dengan metode Single Exponential Smoothing (SES) digunakan dalam peramalan ini. Untuk melakukannya, terlebih dahulu diperlukan model SES dengan menggunakan tools machine learning python bernama statsmodels untuk membuat model, pandas untuk membaca data, dan matplotlib untuk membuat grafik. Grafik dataset pertambahan positif Covid-19 ditunjukkan Gambar 1 berikut ini.

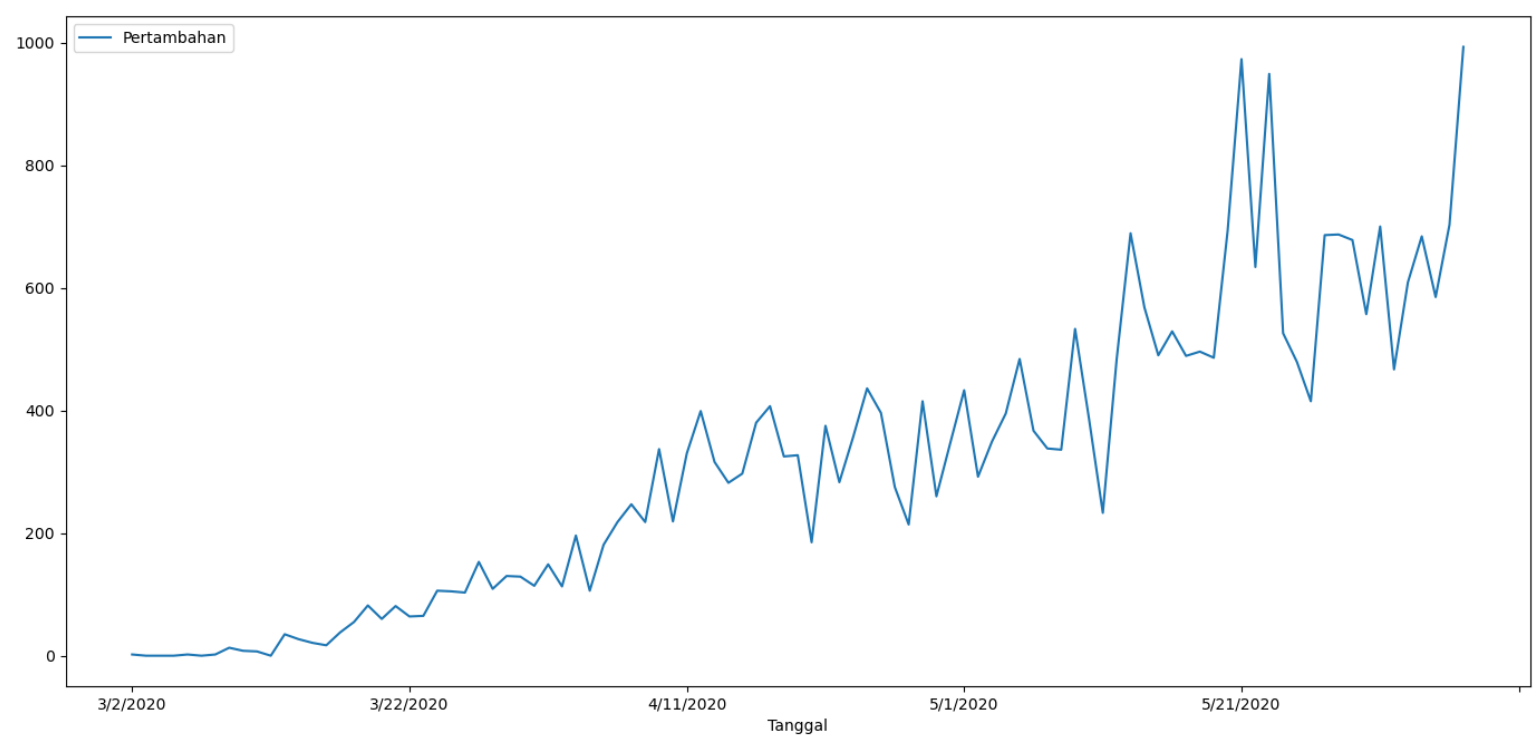

Gambar 1. Grafik Dataset Pertambahan Positif Covid-19

Jika dilihat, jumlah penambahan positif corona bisa dikatakan cukup fluktuatif dan grafik yang naik turun dengan tajam juga membuat peramalan akan menjadi tidak akan terlalu akurat dengan data aktual yang didapatkan. Dengan tidak adanya pola dan trend yang jelas dari dataset tersebut, maka penggunaan SES adalah langkah yang dipilih karena SES cocok dengan dataset yang tidak memiliki pola musiman dan tren. Paramalan dihitung dengan menggunakan beban rata-rata di mana beban terbesar diasosiasikan dengan data terbaru. Sedangkan beban terkecil diasosiasikan dengan data terlama. Dirumuskan dalam persamaan:

$\left.\mathcal{Y}_{\mathrm{T}+1}\right|_{\mathrm{T}}=\alpha \mathcal{Y}_{\mathrm{T}}+\alpha(1-\alpha) y_{\mathrm{T}-1}+\alpha(1-$ $\alpha)^{2} y_{\mathrm{T}-2}+\cdots$

Di mana $0 \leq \alpha \leq 1$ adalah parameter untuk menghaluskan, penurunan beban suatu feature dikontrol oleh parameter penghalus $\alpha$. Semakin besar nilai $\alpha$ maka beban yang diberikan pada 
suatu pengamatan atau data yang baru akan semakin besar juga. Jika $\alpha$ bernilai 0 maka semua hasil ramalan akan bernilai sama dengan rata-rata dataset. Jika $\alpha$ bernilai 1 maka semua hasil ramalan akan bernilai sama dengan data terakhir.
Dalam penelitian ini, dicoba penggunaan 3 varian nilai parameter $\alpha$ yaitu dengan nilai $0.2,0.6$, dan nilai parameter yang disesuaikan dengan sistem statsmodels.

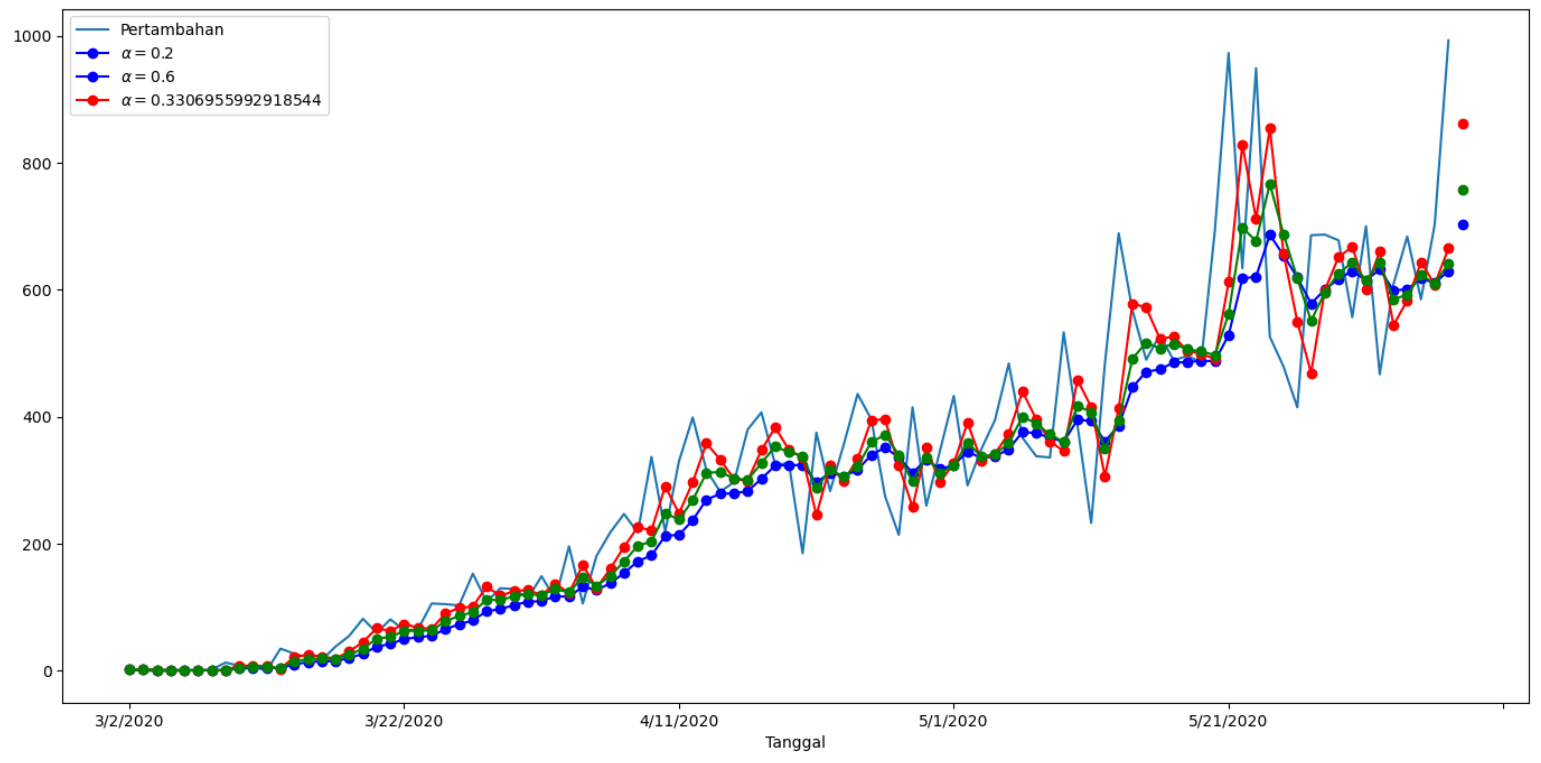

Gambar 2. Hasil dari Analisis Dataset dengan menggunakan Statsmodels

Terdapat 4 garis di grafik tersebut, garis biru muda tanpa titik merupakan data aktual, sedangkan garis hijau merupakan hasil analisis SES dengan $\alpha$ bernilai 0.6 , garis biru tua merupakan hasil analisis SES dengan $\alpha$ bernilai 0.2 , dan garis merah merupakan hasil analisis
SES dengan $\alpha$ bernilai menyesuaikan dengan nilai yang diberikan oleh sistem ststsmodels. Ketiga hasil peramalan tersebut adalah sebagai berikut:

a. $\quad \alpha=0.2: 702$ Positif COVID-19

SimpleExpSmoothing Model Results

\begin{tabular}{|c|c|c|c|}
\hline Dep. Variable: & endog & No. Observations: & 97 \\
\hline Model: & SimpleExpSmoothing & SSE & 1096299.815 \\
\hline Optimized: & False & AIC & 909.276 \\
\hline Trend: & None & $\mathrm{BIC}$ & 914.425 \\
\hline Seasonal: & None & AICC & 909.711 \\
\hline Seasonal Periods: & None & Date: & Sun, 07 Jun 2020 \\
\hline Box-Cox: & False & Time: & $12: 06: 50$ \\
\hline Box-Cox Coeff.: & None & & \\
\hline$==============$ & 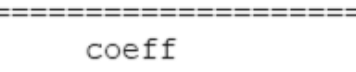 & $\begin{aligned}===== & =========== \\
& \text { code }\end{aligned}$ & $\begin{aligned}== & ============ \\
& \text { optimized }\end{aligned}$ \\
\hline smoothing_level & 0.2000000 & alpha & False \\
\hline initial_lèvel & 2.0000000 & 1.0 & False \\
\hline
\end{tabular}

Gambar 3. Summary perhitungan dengan $\alpha=0.2$

b. $\quad \alpha=0.6: 861$ Positif COVID-19 


\begin{tabular}{|c|c|c|c|}
\hline Dep. Variable: & endog & No. Observations: & 97 \\
\hline Model: & SimpleExpSmoothing & SSE & 1106865.273 \\
\hline Optimized: & False & AIC & 910.206 \\
\hline Trend: & None & $\mathrm{BIC}$ & 915.356 \\
\hline Seasonal: & None & $\mathrm{AICC}$ & 910.641 \\
\hline Seasonal Periods: & None & Date: & Sun, 07 Jun 2020 \\
\hline Box-Cox: & False & Time: & $12: 11: 00$ \\
\hline Box-Cox Coeff.: & None & & \\
\hline & $\operatorname{coeff}$ & code & optimized \\
\hline smoothing level & 0.6000000 & alpha & False \\
\hline initial level & 2.0000000 & 1.0 & False \\
\hline
\end{tabular}

Gambar 4. Summary perhitungan dengan $\alpha=0.6$

c. $\quad \alpha=0.33: 757$ Positif COVID-19

SimpleExpSmoothing Model Results

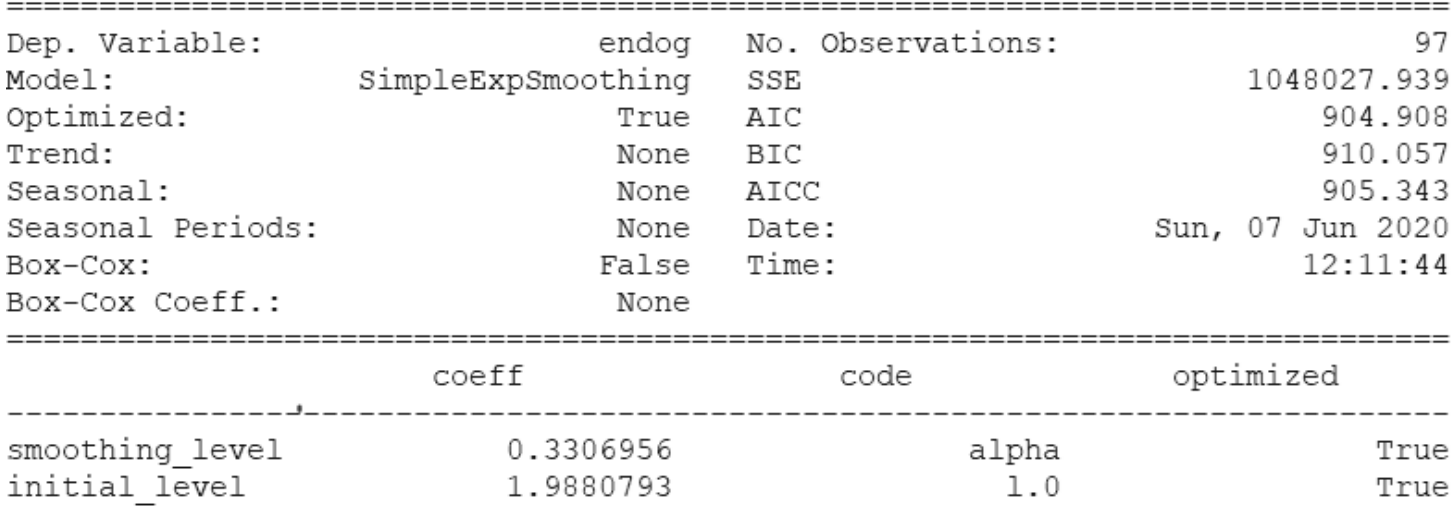

Gambar 5. Summary perhitungan dengan $\alpha$ menyesuaikan Model

Jika melihat grafik pada Gambar 2 menunjukkan garis merah cenderung mendekati pergerakan data aktual sebelum data diprediksi, sedangkan garih hijau cenderung melakukan penghalusan kurva. Lalu garis biru tua merupakan garis yang paling halus kurvanya. Hal ini membuktikan hasil peramalan yang paling baik jika menggunakan $\alpha$ dengan menyesuaikan nilai yang diberikan oleh sistem ststsmodels.

\section{Kesimpulan}

Berdasarkan penelitian yang sudah dilakukan untuk meramalkan pertambahan kasus baru Covid19 Nasional Indonesia. Jika melihat data aktual pada 6 Juni, di mana pada tanggal itu kita ingin memprediksi jumlah pertambahan angka positif COVID-19 dengan data aktual 993 kasus baru. Maka yang mendekati adalah hasil prediksi sebanyak 861 kasus baru dengan parameter $\alpha=0.6$, namun dengan parameter itu memiliki SSE (Sum Squared Error) tertinggi dibandingkan 2 kurva lainnya yaitu 1106865.273 yang artinya memiliki tingkat kesalahan yang cenderung lebih tinggi daripada lainnya. Sedangkan kurva yang yang memiliki SSE terendah adalah kurva merah dengan SSE bernilai 1048027.939. Maka parameter yang paling cocok digunakan adalah bernilai 0.33. Karena angka pertambahan kasus Covid-19 dipengaruhi oleh banyak faktor dan banyak aspek, maka merupakan hal yang sulit untuk menghasilkan angka yang akurat dengan data aktual. Sehingga peramalan angka pertambahan kasus Covid-19 tidak dapat dijadikan patokan untuk mengetahui angka secara pasti pertambahan kasus, mengingat tidak ada pola dan tren yang jelas apalagi jika datanya tidak dijamin kehandalan dan validitasnya. Sehingga hasil dari peramalan pada penelitian ini dengan menggunakan pendekatan time series dan metode SES lebih cocok untuk mengetahui prediksi presentase kenaikan kasusnya saja dibandingkan mengetahui angka pastinya. 


\section{Referensi}

Baharaeen, S., \& Masud, A. S. (1986). A computer program for time series forecasting using single and double exponential smoothing techniques. Computers \& Industrial Engineering, 11(1-4), 151-155. https://doi.org/10.1016/03608352(86)90068-9

Heizer, J., \& Render, B. (2011). Operations Management. Pearson Education Inc.

Liantoni, F., \& Agusti, A. (2020). Forecasting Bitcoin using Double Exponential Smoothing Method Based on Mean Absolute Percentage Error. JOIV : International Journal on Informatics Visualization, 4(2), 91-95. https://doi.org/10.30630/joiv.4.2.335

Liu, M., Ning, J., Du, Y., Cao, J., Zhang, D., Wang, J., \& Chen, M. (2020). Modelling the evolution trajectory of COVID-19 in Wuhan, China: experience and suggestions. Public Health, 183, 76-80.

https://doi.org/10.1016/j.puhe.2020.05.001

Mona, N. (2020). Konsep Isolasi Dalam Jaringan Sosial Untuk Meminimalisasi Efek Contagious (Kasus Penyebaran Virus Corona Di Indonesia). Jurnal Sosial Humaniora Terapan, 2(2). https://doi.org/10.7454/JSHT.V2I2.86

Montgomery, D. C. (n.d.). Introduction to Time Series Analysis and Forecasting. Hoboken, New Jersey: John Wiley \& Sons.
Parhusip, H. A. (2020). Study on COVID-19 in the World and Indonesia Using Regression Model of SVM, Bayesian Ridge and Gaussian. JURNAL $\begin{array}{llll}\text { ILMIAH } & \text { SAINS, } & \text { 20(2), }\end{array}$ https://doi.org/10.35799/jis.20.2.2020.28256

Rosas, A. L., \& Guerrero, V. M. (1994). Restricted forecasts using exponential smoothing techniques. International Journal of Forecasting, 10(4), 515527. https://doi.org/10.1016/01692070(94)90020-5

Rusyida, W. Y., \& Pratama, V. Y. (2020). Prediksi Harga Saham Garuda Indonesia di Tengah Pandemi Covid-19 Menggunakan Metode ARIMA. Square: Journal of Mathematics and Mathematics Education, 2(1), 73. https://doi.org/10.21580/square.2020.2.1.5626

Yuliana, Y. (2020). Corona virus diseases (Covid-19). Wellness And Healthy Magazine, 2(1), 187-192. https://wellness.journalpress.id/wellness/article/vi ew/21026

Zhang, J., Wang, X., Jia, X., Li, J., Hu, K., Chen, G., Wei, J., Gong, Z., Zhou, C., Yu, H., Yu, M., Lei, H., Cheng, F., Zhang, B., Xu, Y., Wang, G., \& Dong, W. (2020). Risk factors for disease severity, unimprovement, and mortality in COVID-19 patients in Wuhan, China. Clinical Microbiology and Infection, 26(6), 767-772. https://doi.org/10.1016/j.cmi.2020.04.012 